\title{
PEMBELAJARAN KOOPERATIF TIPE JIGSAW DALAM MATA KULIAH TEKNOLOGI AIR DAN PENGOLAHAN LIMBAH INDUSTRI
}

\author{
I Nyoman Sukarta dan I Made Gunamantha \\ FMIPA Universitas Pendidikan Ganesha Singaraja \\ (e-mail: inyomansukarta@yahoo.co.id)
}

\begin{abstract}
Abstrak: Pembelajaran Kooperatif Jigsaw dalam Mata Kuliah Tekonologi Air dan Pengolahan Limbah. Penelitian ini bertujuan untuk meningkatkan aktivitas dan hasil belajar mahasiswa pada pembelajaran Teknologi Air dan Pengolahan Limbah Industri melaui penerapan model pembelajaran kooperatif tipe Jigsaw berbantuan reviu pokok bahasan. Subjek penelitian ini adalah mahasiswa jurusan Analis Kimia FMPA Undiksha, sedang objek penelitian adalah aktivitas, hasil belajar, dan respon mahasiswa terhadap strategi pembelajaran yang diterapkan. Hasil penelitian menujukkan bahwa model pembelajaran kooperatif tipe jigsaw berbantuan reviu pokok bahasan dapat meningkatkan aktivitas mahasiswa, tetapi hasil belajar mahasiswa masih belum memuaskan. Respon mahasiswa terhadap pembelajaran yang diterapkan cukup positif. Kendala yang dihadapi dalam pembelajaran ini adalah waktu yang diperlukan cukup banyak dan ketersediaan sumber belajar yang terbatas.
\end{abstract}

Kata Kunci: model pembelajaran kooperatif, aktivitas, respon dan hasil belajar.

\begin{abstract}
The Jigsaw Type Cooperative Teaching Model in the Lecture of Water Technology and Industrial Sewage Treatments. This study was aimed to enhance students' activities and learning achievement in the teaching learning of Water Technology and Industrial Sewage Treatments through the jigsaw type cooperative teaching model based on topic reviews. The subjects were students of the Chemistry Analyst Department of FMPA Undiksha, while the objects were the students' activities, learning achievement, and responses to the teaching. Findings of the study showed that the jigsaw type cooperative learning model based on chapter reviews could increase students' activities. However, the students learning achievement had not reached the expected target. The constraints found in the teaching and learning were that it took a lot of time and there were limited learning resources.
\end{abstract}

Keywords: cooperative learning model, activities, responses, and learning achievement

\section{PENDAHULUAN}

Jurusan Analis Kimia sebagai salah satu Program Studi nonkependidikan di Universitas Pendidikan Ganesha Singaraja, mengemban tugas untuk menghasilkan tenaga-tenaga yang 
tidak hanya cukup memiliki kompetensi inti (profesional di bidangnya), tetapi juga kompetensi generik yaitu memiliki sikap menghormati dan menghargai sesama manusia, menghargai pendapat orang lain, menghargai adanya perbedaan pendapat dalam segala aspek, demokratis, dan sikap-sikap positif lainnya sehingga diharapkan mampu bersaing dalam dunia kerja. Sebagai jurusan yang baru berumur tiga tahun tentu masih jauh untuk segera dapat memenuhi harapan tersebut.

Dari uraian di atas terlihat bahwa Jurusan Analis Kimi dihadapkan pada tantangan yang cukup berat. Dengan demikian, upaya inovasi pengajaran yang mengarah pada kedua kompetensi tersebut mutlak diperlukan pada Jurusan Analis Kimia. Berdasarkan pengalaman dan pengamatan penulis, maka masih kurang adanya kesesuaian pola pengajaran yang dilakukan dengan kedua tuntutan kompetensi tersebut. Padahal, salah satu titik tumpu untuk mencapai itu adalah melalui pengajaran bidang akademis.

Salah satu upaya untuk meningkatkan aktivitas mahasiswa adalah dengan cara mendorong mahasiswa untuk dapat bekerja secara kelompok dalam rangka menumbuhkan daya nalar, cara berpikir logis, sistematis, kreatif, cerdas, terbuka dan ingin tahu. Oleh karenaitu, dalam kegiatan belajar mengajar perlu dikembangkan pengalamanpengalaman belajar melalui pendekatan dan inovasi model-model pembelajaran yang sesuai (Yusuf, 2003). Pembelajaran ilmu kimia terapan seperti mata kuliah Teknologi Air dan Pengolahan Limbah Industri, dapat diarah- kan pada kegiatan-kegiatan yang mendorong mahasiswa belajar secara aktif, baik fisik, mental intelektual, maupun sosial (kelompok) kususnya.

Untuk dapat mengatasi persoalan tersebut diperlukan pembelajaran dengan pendekatan kelompok yang berbasis pada aktivitas mahasiswa yang berorientasi pengetahuan awal yang lebih memadai sebelum mengikuti perkuliahan dan pemecahan masalah berdasarkan keterlibatan mahasiswa dalam pembelajaran (Cooper, 1995, Ibrahim dkk, 2000, Jacob, dkk, 1996). Dengan demikian, pembelajaran yang mungkin dilakukan adalah pembelajaran yang identik dengan diskusi kelompok dengan model pembelajaran kooperatif Jigsaw berbantuan reviu pokok bahasan.

Dewasa ini telah banyak digunakan model pembelajaran kooperatif. Bahkan, pembelajaran kooperatif ini merupakan salah satu model yang banyak dikembangkan. Beberapa ahli menyebutkan bahwa model pembelajaran kooperatif tidak hanya unggul membantu siswa untuk memahami konsep-konsep tetapi juga membantu siswa menumbuhkan kemampuan kerja sama, berpikir kritis dan mengembangkan sikap sosial siswa (Nur dan Wikandari, 1998). Di samping itu, keterampilan kooperatif menjadi semakin penting untuk keberhasilan dalam menghadapi tuntutan lapangan kerja yang sekarang ini berorientasi pada kerjasama tim. Karena pentingnya interaksi dalam tim maka penerapan strategi pembelajaran kooperatif dalam pendidikan menjadi lebih penting (Retug dan Syaban, 2004) 
Dalam pembelajaran kooperatif terdapat bermacam-macam tipe, salah satunya adalah pembelajaran kooperatif tipe Jigsaw. Lie menyebutkan bahwa Jigsaw merupakan salah satu tipe metode pembelajaran yang fleksibel. Model pembelajaran kooperatif tipe Jigsaw sangat relevan jika dilaksanakan dengan tugasmembuat reviu. Tugas membuat reviu dapat digunakan untuk mengeksplorasi pengetahuan awal mahasiswa dan pembelajaran kooperatif tipe Jigsaw sebagai upaya untuk menumbuhkan kemampuan kerja sama, membantu mahasiwa berpikir kritis dalam memecahkan persoalan-persoalan yang dihadapi selama melakukan percobaan dan mengembangkan sikap sosial mahasiswa. Permasalahan-permasalahan tersebut dapat dirinci melalui pertanyaan penelitian sebagai berikut. (1) Apakah dengan penerapan model pembelajaran kooperatif tipe Jigsaw pada mata kuliah Teknologi Air dan Pengolahan Limbah Industri dapat meningkatkan aktivitas mahasiswa. (2) Apakah dengan penerapan model pembelajaran kooperatif tipe Jigsaw pada mata kuliah Teknologi Air dan Pengolahan Limbah Industri dapat meningkatkan hasil belajar mahasiswa. (3) Bagaimanakah persepsi mahasiswa terhadap penerapan model pembelajaran kooperatif dengan tipe Jigsaw dalam perkuliahan Teknologi Air dan Pengolahan Limbah Industri.

\section{METODE}

Penelitian ini merupakan penelitian tindakan kelas (PTK) yang terdiri dari dua siklus. Subjek dalam penelitian ini adalah mahasiswa yang mengkuti per- kuliahan Teknologi Air dan Pengolahan Limbah Industri di Jurusan Analis Kimia FMIPA Universitas Pendidikan Ganesha Singaraja tahun akademik 2005/2006. Objek penelitian ini adalah aktivitas mahasiswa dalam kegiatan perkuliahan di kelas, hasil belajar mahasiswa, dan persepsi mahasiswa terhadap model pembelajaran yang diterapkan.

Pada penelitian ini, diterapkan model pembelajaran tipe jigsaw, yang mana terdapat kelompok asal dan kelompok ahli. Kelompok asal yaitu kelompok induk mahasiswa yang beranggotakan mahasiswa dengan kemampuan, asal dan latar belakang keluarga yang beragam. Kelompok asal merupakan gabungan dari beberapa ahli. Kelompok ahli, yaitu kelompok mahasiswa yang terdiri dari anggota kelompok asal yang berbeda yang ditugaskan untuk mempelajari dan mendalami topik tertentu dan menyelesaikan tugas-tugas yang berhubungan dengan topicnya untuk kemudian dijelaskan pada anggota kelompok asal. Hubungan antara kelompok asal dan kelompok ahli digambarkan seperti Gambar 1.

Para anggota kelompok asal yang berbeda, bertemu dengan topik yang sama dalam kelompok ahli untuk berdiskusi dan membahas materi yang ditugaskan pada masing-masing anggota kelompok serta membantu satu sama lain untuk mempelajari topik mereka tersebut. Setelah pembahasan selesai, para anggota kelompok kemudian kembali pada kelompok asal dan mengajarkan pada teman sekolompoknya yang telah mereka dapatkan pada saat pertemuan kelompok ahli. Setelah diskusi 
kelompok dilanjutkan dengan diskusi kelas. Salah satu kelompok mempresentasikan hasil diskusi kelompoknya kemudian dilanjutkan dengan diskusi kelas.

\section{Kelompok Asal}

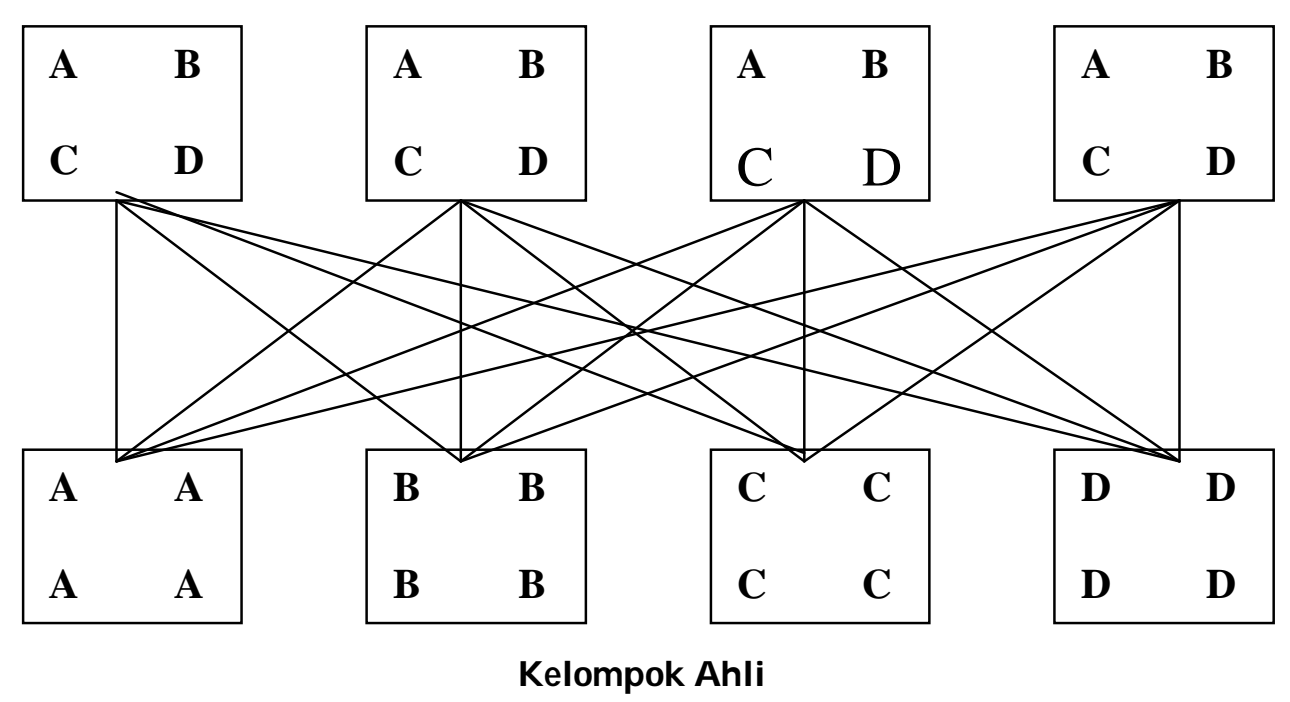

Gambar 1. Ilustrasi kelompok Jigsaw

Jigsaw didesain selain untuk meningkatkan rasa tanggung jawab siswa secara mandiri juga dituntut saling ketergantungan yang positif (saling memberi tahu) terhadap teman sekelompoknya. Siswa tidak hanya mempelajari materi yang diberikan, tetapi mereka juga harus siap memberikan dan mengajarkan materi tersebut kepada anggota kelompoknya yang lain. Dengan demikian siswa tidak hanya saling ketergantungan antara siswa yang satu satu dengan yang lain, tetapi juga harus dapat bekerja sama untuk mempelajari materi yang ditugaskan oleh dosen.

Penelitian ini terdiri dari empat tahapan, yaitu (1) perencanaan; (2) pelaksanaan; (3) observasi dan evaluasi; dan (4) refleksi. Mata Kuliah Teknologi Air dan Pengolahan Limbah Industri ter- diri dari 4 pokok bahasan, yaitu Penyediaan air bersih, Tinjauan Standar Kualitas Air Minum, Proses Pengolahan Air dan Proses Pengolahan Limbah Industri. Pada Penelitian ini model pembelajaran kooperatif hanya diterapkan pada dua pokok bahasan. Dalam satu semester kegiatan belajar berlangsung antara 14-16 kali pertemuan. Penelitian ini dirancang dalam dua siklus. Setiap siklus terdiri dari 1 pokok bahasan. Setiap pokok bahasan terdiri dari 4 topik ahli yaitu dari Bab I. Karakteristik Sumber-sumber Air dibagi menjadi 4 topik ahli yaitu Air, Danau, Tanah dan Atmosfer. Bab II untuk sub bab Faktor Fisika Perairan terdiri dari 4 topik ahli yaitu Zat Padat, Suhu, Cahaya dan Warna. Untuk sub bab Faktor Kimia dan Mikrobiologi Perairan terdiri dari 8 
topik ahli, yaitu Karbondioksida, Oksigen Terlarut, Kesadahan, Bahan Organik, Nitrit dan Nitrat, Fosfor, Besi dan Mikrobiologi. Topik-topik ahli pada bab I dan sub bab Faktor Fisika Perairan merupakan topik-topik yang dibahas pada siklus I sedangkan topik pada Faktor Kimia dan Mikrobiologi perairan dibahas pada siklus II.

Teknikpengumpulan data disesuaikan dengan jenis data yang diperlukan seperti disajikan pada Tabel 1 berikut.

Tabel 1. Teknik Pengumpulan Data

\begin{tabular}{|c|c|c|c|}
\hline No & Jenis Data & Teknik & Instrumen \\
\hline 1 & $\begin{array}{l}\text { Prior knowledge dan kesiapan belajar } \\
\text { mahasiswa }\end{array}$ & $\begin{array}{l}\text { Penilaian terhadap } \\
\text { dokumen (tugas reviu) }\end{array}$ & $\begin{array}{l}\text { Pedoman penilaian (tugas } \\
\text { reviu) }\end{array}$ \\
\hline 2 & $\begin{array}{l}\text { Aktivitas atau perilaku mahasiswa } \\
\text { dalam pembelajaran }\end{array}$ & Observasi & Pedoman observasi \\
\hline 3 & Hasil belajar mahasiswa & $\begin{array}{l}\text { Tes, tugas dan laporan } \\
\text { praktikum }\end{array}$ & $\begin{array}{l}\text { Tes hasil belajar, laporan } \\
\text { praktikum dan tugas }\end{array}$ \\
\hline 4 & $\begin{array}{l}\text { Kendala-kendala implementasi } \\
\text { model pembelajaran }\end{array}$ & Observasi & $\begin{array}{l}\text { Jurnal/catatan harian } \\
\text { peneliti }\end{array}$ \\
\hline 5 & Persepsi mahasiswa & Kuisioner & Angket \\
\hline
\end{tabular}

Data yang diperoleh dalam penelitian ini dianalisis secara deskriptif interpretatif. Data aktivitas atau prilaku mahasiswa dalam pembelajaran dan persepsi mahasiswa dinyatakan dalam bentuk frekuensi selanjutnya diprosentasekan. Berdasarkan frekuensi (persentase) tersebut dilakukan interpretasi oleh peneliti bersama tim pengajar sampai diperoleh simpulan tentang aktivitas mahasiswa dalam pembelajaran dan persepsi mahasiswa. Data hasil belajar dianalisis sampai diperoleh tingkat ketuntasan belajar baik ketuntasan individual dan kelas.

Sebagai ukuran keberhasilan digunakan patokan seperti di bawah ini.

- Aktivitas ukuran mahasiswa dalam pembelajaran baik.

- Mahasiswa dinyatakan berhasil jika sudah mencapai nilai lulus dengan nilai A, B, atau C. Proporsi nilai A dan B lebih besar daripada C.
- Perkuliahan dianggap berhasil jika lebih dari 85\% mahasiswa berhasil memperoleh nilai A dan/atau B.

- Persepsi mahasiswa terhadap penyelenggaraan pembelajaran positif.

\section{HASIL}

Sesuai dengan tujuan penelitian ini, yaitu mengetahui aktivitas belajar mahasiswa, hasil belajar mahasiswa dan respon mahasiswa dalam pembelajaran dengan penerapan model pembelajaran kooperatif tipe Jigsaw berbantuan reviu pokok bahasan untuk meningkatkan aktivitas dan hasil belajar mahasiswa dalam mata kuliah Teknologi Air dan Pengolahan Limbah Industri, maka beberapa aspek yang dinilai atau diobservasi adalah (1) aktivitas mahasiswa dalam pembelajaran; (2) hasil belajar mahasiswa: nilai tugas dan nilai tes; dan (3) respon mahasiswa terhadap penyelenggaraan pembelajaran. Data tentang 
aktivitas belajar, hasil belajar dan res- turut disajikan pada Tabel 2, 3 dan 4 pon mahasiswa pada siklus I berturut- berikut.

Tabel 2. Data Aktivitas Belajar Mahasiswa Siklus I

\begin{tabular}{|c|c|c|c|c|c|c|c|c|c|c|c|c|}
\hline \multirow{3}{*}{ Aspek yang dinilai/diobservasi } & \multicolumn{10}{|c|}{ Kategori } & \multirow{3}{*}{ Rerata } & \multirow{3}{*}{ Partisipan } \\
\hline & \multicolumn{2}{|r|}{ A } & \multicolumn{2}{|c|}{ B } & \multicolumn{2}{|c|}{$\mathrm{C}$} & \multicolumn{2}{|c|}{$\mathbf{D}$} & \multicolumn{2}{|c|}{$\mathbf{E}$} & & \\
\hline & $\mathbf{n}$ & $\%$ & $\mathbf{n}$ & $\%$ & $\mathbf{n}$ & $\%$ & $\mathbf{n}$ & $\%$ & $\mathbf{n}$ & $\%$ & & \\
\hline $\begin{array}{l}\text { Antusiasme mahasiswa dalam } \\
\text { mengikuti perkuliahan }\end{array}$ & 7 & 32 & 3 & 14 & 8 & 36 & 1 & 4 & 3 & 14 & $\begin{array}{c}2 \\
\text { (cukup) }\end{array}$ & 22 Orang \\
\hline $\begin{array}{l}\text { Tanggung jawab mahasiswa terhadap } \\
\text { tugas }\end{array}$ & 7 & 32 & 5 & 23 & 6 & 27 & 3 & 14 & 1 & 4 & $\begin{array}{c}3 \\
\text { (baik) }\end{array}$ & \\
\hline $\begin{array}{l}\text { Kemampuan menyampaikan penda- } \\
\text { pat dan menghargai pendapat orang } \\
\text { lain }\end{array}$ & 4 & 18 & 5 & 23 & 5 & 23 & 4 & 18 & 4 & 18 & $\begin{array}{c}2 \\
\text { (cukup) }\end{array}$ & \\
\hline $\begin{array}{l}\text { Kerjasama kelompok dalam } \\
\text { pembelajaran }\end{array}$ & 3 & 14 & 7 & 32 & 8 & 36 & 4 & 18 & - & & $\begin{array}{c}2 \\
\text { (cukup) }\end{array}$ & \\
\hline
\end{tabular}

Tabel 3. Nilai Tugas Reviu Pokok Bahasan Siklus I

\begin{tabular}{ccccc}
\hline Tingkat & \multicolumn{2}{c}{ Nilai } & \multicolumn{2}{c}{ Jumlah Mahasiswa } \\
\cline { 2 - 5 } Penguasaan & Angka & Huruf & $\mathbf{n}$ & $\%$ \\
\hline $85 \%-100 \%$ & 4 & $\mathrm{~A}$ & 5 & 23 \\
$70 \%-84 \%$ & 3 & $\mathrm{~B}$ & 17 & 77 \\
$55 \%-69 \%$ & 2 & $\mathrm{C}$ & & \\
$40 \%-54 \%$ & 1 & $\mathrm{D}$ & & \\
$0 \%-39 \%$ & 0 & $\mathrm{E}$ & & \\
\hline
\end{tabular}

Tabel 4. Nilai Tes Hasil Belajar Mahasiswa Siklus I $(\mathbf{n}=22)$

\begin{tabular}{ccccc}
\hline Tingkat & \multicolumn{2}{c}{ Nilai } & \multicolumn{2}{c}{ Jumlah Mahasiswa } \\
\cline { 2 - 5 } Penguasaan & Angka & Huruf & n & $\%$ \\
\hline $85 \%-100 \%$ & 4 & A & 3 & 14 \\
$70 \%-84 \%$ & 3 & B & 16 & 72 \\
$55 \%-69 \%$ & 2 & C & 3 & 14 \\
$40 \%-54 \%$ & 1 & D & & \\
$0 \%-39 \%$ & 0 & E & & \\
\hline
\end{tabular}

Keterangan $\mathrm{n}=$ jumlah mahasiswa

Data tentang aktivitas belajar, hasil lus II berturut-turut disajikan pada belajardan respon mahasiswa pada sik- Tabel 5, 6 dan 7 berikut. 
Tabel 5. Nilai Aktivitas Mahasiswa pada Siklus II

\begin{tabular}{|c|c|c|c|c|c|c|c|c|c|c|c|}
\hline \multirow{3}{*}{ Aspek yang dinilai/diobservasi } & \multicolumn{9}{|c|}{ Kategori } & \multirow{3}{*}{ Rerata } & \multirow{3}{*}{ Partisipan } \\
\hline & \multicolumn{2}{|r|}{ A } & \multicolumn{2}{|c|}{ B } & \multicolumn{2}{|c|}{$\mathrm{C}$} & \multicolumn{2}{|c|}{$\mathbf{D}$} & $\mathrm{E}$ & & \\
\hline & $\mathrm{n}$ & $\%$ & $\mathbf{n}$ & $\%$ & $\mathrm{n}$ & $\%$ & $\mathrm{n}$ & $\%$ & n $\%$ & & \\
\hline $\begin{array}{l}\text { Antusiasme mahasiswa dalam } \\
\text { mengikuti perkuliahan }\end{array}$ & 4 & 418 & 10 & 46 & 6 & 27 & 2 & 9 & & $\begin{array}{c}2 \\
\text { (cukup) }\end{array}$ & 22 \\
\hline $\begin{array}{l}\text { Tanggung jawab mahasiswa terhadap } \\
\text { tugas }\end{array}$ & 4 & 418 & 7 & 32 & 8 & 36 & 2 & 9 & 15 & $\begin{array}{c}2.5 \\
\text { ( baik) }\end{array}$ & \\
\hline $\begin{array}{l}\text { Kemampuan menyampaikan } \\
\text { pendapat dan menghargai pendapat } \\
\text { orang lain }\end{array}$ & 4 & 418 & 10 & 46 & 6 & 27 & 2 & 9 & & 3 (baik) & \\
\hline $\begin{array}{l}\text { Kerjasama kelompok dalam } \\
\text { pembelajaran }\end{array}$ & 3 & 314 & 10 & 46 & 6 & 27 & 3 & 13 & & 3 (baik) & \\
\hline
\end{tabular}

Tabel 6. Nilai Tugas Reviu Pokok Bahasan Siklus II

\begin{tabular}{ccccc}
\hline \multirow{2}{*}{ Tingkat Penguasaan } & \multicolumn{2}{c}{ Nilai } & \multicolumn{2}{c}{ Jumlah Mahasiswa } \\
\cline { 2 - 5 } & Angka & Huruf & n & $\%$ \\
\hline $85 \%-100 \%$ & 4 & A & 22 & \\
$70 \%-84 \%$ & 3 & B & & \\
$55 \%-69 \%$ & 2 & C & & \\
$40 \%-54 \%$ & 1 & D & & \\
$0 \%-39 \%$ & 0 & E & \\
\hline
\end{tabular}

Tabel 7 Nilai Hasil Belajar pada Siklus II

\begin{tabular}{ccccc}
\hline \multirow{2}{*}{ Tingkat Penguasaan } & \multicolumn{2}{c}{ Nilai } & \multicolumn{2}{c}{ Jumlah Mahasiswa } \\
\cline { 2 - 5 } & Angka & Huruf & n & $\%$ \\
\hline $85 \%-100 \%$ & 4 & A & 5 & 23 \\
$70 \%-84 \%$ & 3 & B & 12 & 54 \\
$55 \%-69 \%$ & 2 & C & 5 & 23 \\
$40 \%-54 \%$ & 1 & D & & \\
$0 \%-39 \%$ & 0 & E & & \\
\hline
\end{tabular}




\section{PEMBAHASAN}

\section{Aktivitas Belajar Mahasiswa}

Aktivitas belajar dinilai berdasarkan aspek-aspek (1) antusiasme dalam mengikuti perkuliahan; (2) tanggung jawab mahasiswa dalam menyelesaikan tugas; (3) kemampuan menyampaikan pendapat dan menghargai orang lain; dan (4) kerjasama kelompok dalam pembelajaran. Dari keempat aspek tersebut kecuali antusiasme mahasiswa dalam mengikuti perkuliahan terjadi peningkatan aktivitas belajar mahasiswa dari kategori cukup pada siklus I menjadi baik pada siklus II. Walaupun memang untuk aspek tanggung jawab terhadap tugas tetap dalam kategori baik. Terjadinya aspek antusiame mahasiswa dalam mengikuti perkuliahan masih pada kategori cukup pada siklus II dimungkinkan karena mahasiswa sudah jenuh dalam melakukan diskusi karena harus mengikuti tiga tahapan diskusi pada beberapa kelompok topik ahli. Ketiga tahapan diskusi tersebut yaitu diskusi kelompok ahli, diskusi kelompok dan diskusi kelas. Walaupun demikian perubahan juga terjadi pada aspek ini dimana pada siklus II sudah tidak terdapat mahasiswa yang lainlain atau kurang perhatian dalam diskusi. Pada diskusi kelompok ahli pada siklus I hampir sebagian waktu dihabiskan membaca tugas yang dibawa masing-masing sehingga diskusi kelompok menjadi sangat pasif. Para anggota ahli (mahasiswa) masih saling menunggu untuk mengawali diskusi. Dibandingkan dengan siklus II kesiapan mahasiswa dalam penguasaan materi rata-rata lebih baik. Hal ini dikarenakan materi pada siklus I relatif lebih mudah untuk dipahami dibandingkan dengan materi-materi (topiktopik ahli) pada siklus II. Secara keseluruhan, terjadinya peningkatan aktivitas pada siklus II dikarenakan mahasiwa sudah tidak canggung lagi dengan model pembelajaran yang diterapkan dan dengan mahasiswa lainnya karena mereka sudah beberapa kali melakukan diskusi. Mahasiswa lebih berani menyampaikan pendapat, lebih bertanggung jawab terhadap tugas, lebih terbuka terhadap anggota kelompok lainnya sehingga komunikasi dan kerjasama bisa berlangsung lebih baik. Hal ini didukung pula dari hasil angket tertutup dan terbuka.

Peningkatan aktivitas mahasiswa juga terjadi karena dalam pembelajaran ini mahasiswa secara aktif membangun pengetahuan mereka sendiri, otak siswa sebagai mediator, yaitu memproses masukan dari dunia luar dan menentukan apa yang mereka pelajari. Pembelajaran merupakan kerja mental aktif, bukan menerima pengajaran dari guru atau dosen secara pasif. Dalam kerja mental mahasiswa, guru atau dosen memegang peranan penting dengan cara memberikan dukungan, tantangan berpikir, melayani sebagai pelatih bukan memberikan ceramah atau mengendalikan seluruh kegiatan kelas.

Menurut pandangan konstruktivisme dalam pembelajaran didasarkan oleh 4 prinsip (Fosnot , 1989 ) sebagai berikut. (1) Pengetahuan terdiri dari "Post Construction" bahwa manusia mengkonstruksi pengalamannya melalui suatu kerangka logis yang mentransformasikan, mengorganisasikan, dan menginterpretasikan pengalaman- 
nya. Struktur logis tersebut berkembang analog dengan perkembangan biologis. (2) Pengkonstruksian pengetahuan terjadi melalui proses asimilasi dan akomodasi. Manusia menggunakan proses asimilasi sebagai suatu kerangka logis dalam rangka menginterpretasikan informasi baru, dan dengan akomodasi dalam rangkan memecahkan kontradiski-kontradiksi sebagai bagian dari proses regulasi diri yang lebih luas. (3) Mengacu kepada belajar sebagai proses organik penemuan lebih dari pada proses mekanik akumulasi. Kaum konstruktivis mengambil suatu posisi bahwa pebelajar harus mendapat pengalaman berhipotesis, memprediksi, memanipulasi objek, mengajukan pertanyaan, mencari jawaban, berimajinasi dan menemukan dalam upaya mengembangkan konstruksi-konstruksi baru. (4) Belajar bermakna terjadi melalui refleksi dan pemecahan konflik kognitif.

Pendekatan konstruktivis dalam pengajaran merupakan pembelajaran kooperatif secara luas, berdasarkan teori bahwa siswa lebih mudah menemukan dan memahami konsep-konsep yang sulit jika mereka saling mendiskusikan masalah tersebut dengan temannya. Siswa secara rutin bekerja dalam kelompok untuk saling membantu memecahkan masalah-masalah yang kompleks. Oleh karena itu, perlu dilakukan upaya untuk mengatur aktivitas di dalam kelas yang terdiri dari individu-individu ke dalam bentuk kelompok-kelompok kecil siswa daripada dalam bentuk klasikal. Hal ini sesuai dengan pendekatan konstruktivis da- lam pembelajaran yang menerapkan pembelajaran kooperatif.

\section{Hasil Belajar}

Hasil belajar mahasiswa diukur menggunakan dua parameter, (1) penilaian terhadap tugas-tugas, yaitu tugas membuat reviu dan laporan praktikum; dan 2) penilaian hasil belajar dengan tes hasil belajar.

Dari siklus I, dan II diperoleh nilai tugas mahasiswa sudah baik, bahkan sangat baik. Kelemahan yang masih ada adalah buku-buku rujukan yang digunakan mahasiswa masih sangat terbatas, sebagian besar mahasiswa mengacu pada Buku Ajar di samping kurang dalamnya materi yang disajikan juga mahasiswa kurang dapat memanfaatkan jenis sumber belajar di luar kelas. Nilai laporan praktikum dari kedua siklus keduanya dalam kategori baik. Laporan praktikum merupakan rangkaian dari kegiatan praktikum yang menjadi satu kesatuan pada mata kuliah Teknologi Air dan Pengolahan Limbah Industri.

Hasil belajar mahasiswa dari tes hasil belajar menunjukkan bahwa terjadi penurunan dari siklus I ke siklus II, terutama kalau dilihat dari meningkatnya porsi nilai C dari $14 \%$ pada siklus I menjadi $23 \%$ pada siklus II dan terjadinya penurunan porsi nilai $\mathrm{B}$ dari $72 \%$ pada siklus I menjadi $54 \%$ pada siklus II. Peningkatan nilai A dari 14\% menjadi $23 \%$ tidak dapat mengimbangi peningkatan porsi nilai C. Secara keseluruhan, tes hasil belajar menunjukkan penurunan dari siklus I ke siklus II. Penurunan tes hasil belajar ini disebabkan oleh karena tingkat kesulitan materi 
pada siklus II lebih berat dibandingkan dengan materi pada siklus I. Kalau dilihat dari proporsi nilai A dan B baik pada siklus I maupun siklus II masih lebih besar bila dibandingkan dengan proporsi nilai C. Kriteria keberhasilan tindakan sebagaimana ditetapkan bahwa perkuliahan dianggap berhasil jika lebih dari 85\% mahasiswa berhasil memperoleh nilai A dan/atau B. Berdasarkan data tersebut di atas keberhasilan tindakan hanya terjadi pada siklus I yaitu dengan proporsi nilai A dan/atau B sebesar $86 \%$. Sedangkan pada siklus II mahasiswa yang memperoleh nilai A dan/atau B hanya 77\%. Rendahnya proporsi nilai A dan/atau B pada siklus II karena materi pada siklus II lebih sulit dibandingkan dengan materi pada siklus I. Hal ini kemungkinan disebabkan mahasiswa mengalami kesulitan dalam memahami beberapa konsep dan tidak dapat didiskusikan dengan baik pada diskusi kelompok ahli sehingga tidak dapat menjelaskan dengan baik pada diskusi kelompok asalnya. Pernyataan ini didukung oleh hasil penyebaran angket dimana beberapa mahasiswa merasa tidak dapat membantu temannya artinya kurang dapat memberikan penjelasan dengan baik karena tidak menguasai dengan baik topik ahli yang ditugaskan kepada mahasiswa bersangkutan. Sebagian besar mahasiswa juga menyatakan kesulitan didalam memahami penjelasan dari temannya baik dalam kelompok ahli maupun dalam disikusi kelompok asal. Dan terungkap pula bahwa mahasiswa hanya menggunakan buku ajar sebagai satu-satunya sumber belajar. Secara keseluruhan tindakan belum berhasil karena proporsi mahasiswa yang memperoleh nilai A dan/atau B hanya $82 \%$. Walaupun demikian skor ini tidak berarti bahwa tinndakan ini gagal karena harus pula dilihat dari aspek-aspek lainnya.

Aspek-aspek lain yang dicapai dalam model pembelajaran kooperatif ini setidak-tidaknya ada tiga tujuan pembelajaran penting yang dirangkum oleh Ibrahim, et al. (2000) sebagai berikut.

- Hasil belajar akademik

Dalam belajar kooperatif meskipun mencakup beragam tujuan sosial, juga memperbaiki prestasi mahasiswa atau tugas-tugas akademis penting lainnya. Beberapa ahli berpendapat bahwa model ini unggul dalam membantu mahasiswa memahami konsep-konsep sulit. Para pengembang model ini telah menunjukkan bahwa model struktur penghargaan kooperatif telah dapat meningkatkan nilai mahasiswa pada belajar akademik dan perubahan norma yang berhubungan dengan hasil belajar. Di samping mengubah norma yang berhubungan dengan hasil belajar, pembelajaran kooperatif dapat memberi keuntungan baik pada mahasiswa kelompok bawah maupun kelompok atas yang bekerja bersama menyelesaikan tugas-tugas akademik.

- Penerimaan terhadap perbedaan individu

Tujuan lain model pembelajaran kooperatif penerimaan secara luas dari orang-orang yang berbeda berdasarkan ras, budaya, kelas sosial, kemampuan dan ketidakmampuannya. 
Pembelajaran kooperatif memberi peluang bagi mahasiswa dari berbagai latar belakang dan kondisi untuk bekerja dengan saling bergantung pada tugas-tugas akademik dan melalui struktur penghargaan kooperatif akan belajar saling menghargai satu sama lain.

- Pengembangan ketrampilan sosial Tujuan penting ketiga pembelajaran $\mathrm{k}$ o o p e r a t if adalah mengajarkan kepada mahasiswa keterampilan bekerja sama dan kolaborasi. Keterampilan-keterampilan sosial, penting dimiliki oleh mahasiswa sebab saat ini banyak anak muda masih kurang dalam ketrampilan sosial.

Dalam pembelajaran koopertif tidak hanya mempelajari materi saja, tetapi mahasiswa atau peserta didik juga harus mempelajari keterampilan-keterampilan khusus yang disebut keterampilan kooperatif. Keterampilan kooperatif ini berfungsi untuk melancarkan hubungan kerja dan tugas. Peranan hubungan kerja dapat dibangun dengan membangun tugas anggota kelompok selama kegiatan. Keterampilanketampilan kooperatif tersebut antara lain sebagai berikut (Lungdren, 1994).

- Ketrampilan kooperatif tingkat awal

- Menggunakan kesepakatan

Yang dimaksud dengan menggunakan kesepakatan adalah menyamakan pendapat yang berguna untuk meningkatkan hubungan kerja dalam kelompok.

- Menghargai kontribusi

Menghargai berarti memperhatikan atau mengenal apa yang dapat dikatakan atau dikerjakan anggota lain. Hal ini berarti harus selalu setuju dengan anggota lain, dapat saja kritik yang diberikan itu ditujukan terhadap ide dan tidak individu.

- Mengambil giliran dan berbagi tugas

Pengertian ini mengandung arti bahwa setiap anggota kelompok bersedia menggantikan dan bersedia mengemban tugas/tanggungjawab tertentu dalam kelompok.

- Berada dalam kelompok

Maksud di sini adalah setiap anggota tetap dalam kelompok kerja selama kegiatan berlangsung.

- Berada dalam tugas

Yang dimaksud berada dalam tugas adalah meneruskan tugas yang menjadi tanggungjawabnya, agar kegiatan dapat diselesaikan sesuai waktu yang dibutuhkan.

- Mendorong partisipasi

Mendorong partisipasiberarti mendorong semua anggota kelompok untuk memberikan kontribusi terhadap tugas kelompok.

- Mengundang orang lain

Maksudnya adalah meminta orang lain untuk berbicara dan berpartisipasi terhadap tugas.

- Menyelesaikan tugas dalam waktunya

- Menghormati perbedaan individu Menghormati perbedaan individu berarti bersikap menghormati terhadap budaya, membuat ringkasan, menafsirkan, mengorganisir, dan mengurangi ketegangan.

- Keterampilan tingkat menengah

Keterampilan tingkat menengah meliputi menunjukkan penghargaan dan simpati, mengungkapkan ke- 
tidaksetujuan dengan cara diterima, mendengarkan denngan arif, bertanya, membuat ringkasan, menafsirkan, mengorganisir dan mengurangi ketegangan.

- Keterampilan tingkat mahir

Keterampilan tingkat mahir meliputi mengelaborasi, memeriksa dengan cermat, menanyakan kebenaran, menetapkan tujuan dan berkompromi.

\section{Persepsi Mahasiswa}

Dari angket yang disebarkan menunjukkan bahwa persepsi mahasiswa terhadap model pembelajaran ini sangat baik. Sebagian besar mahasiswa berpendapat bahwa model pembelajaran ini dapat diteruskan. Walaupun dilihat dari tes hasil belajar yang belum dapat memenuhi tingkat keberhasilan tindakan ini tetapi model pembelajaran ini baik untuk meningkatkan kecakapan sosial mahasiswa.

Berdasarkan hasil rangkuman pendapat mahasiswa melalui angket terbuka, pengelolaan model pembelajaran kooperatif tipe Jigsaw memiliki beberapa keunggunlan diantaranya adalah melatih kemampuan berbicara dan mengemukakan pendapat, melatih mahasiswa dalam berdiskusi dan pemahaman konsep terhadap materi lebih baik. Kelemahan model pembelajaran ini menurut mahasiswa adalah pemahaman terhadap materi hanya terbatas pada topik ahli yang ditugaskan, waktu untuk diskusi kelompok ahli maupun presentasi kelas cukup banyak sehingga dari alokasi waktu kuliah yang tersedia dirasa masih kurang. Sedangkan kendala yang dihadapi mahasiswa adalah kterbatasan sumber belajar dan kurang efektifnyaa diskusi kelompok yang dilakukan di luar perkuliahan.

Dari keunggulan, kelemahan dan kendala-kendala yang dihadapi mahasiswa dalam mengikuti perkuliahan dengan model pembelajaran kooperatif tipe Jigsaw ini, mahasiswa mengajukan saran-saran agar diskusi kelompok asal dilakukan pada jam perkuliahan sehingga diskusi dapat dilaksana dengan lebih baik di bawah pengawasan dosen pengajar sehingga penguasaan terhadap materi tidak hanya pada topik ahli yang ditugaskan juga terhadap topik-topik ahli lainnya yang ditugaskan kepada mahasiswa yang lain. Mengingat waktu yang akan diperlukan untuk melakukan diskusi kelompok asal pada jam perkuliahan akan menyita waktu lebih banyak mahasiswa menyarankan agar topik ahli tidak terlalu banyak sehingga pengelolaan waktu bisa lebih baik dan tidak membosankan.

\section{PENUTUP}

\section{Kesimpulan}

Berdasarkan hasil penelitian ini, dapat dibuat simpulan sebagai berikut.

- Penerapan model pembelajaran kooperatif tipe Jigsaw berbantuan reviu pokok bahasan untuk meningkatkan aktivitas dan hasil belajar mahasiswa dalam mata kuliah Teknologi Air dan Pengolahan Limbah Industri dapat meningkatkan kualitas pembelajaran dan melatih keterampilan sosial mahasiswa. Kemampuan komunikasi, kerja sama dan mening- 
katkan rasa tanggung jawab mahasiswa terhadap tugas.

- Penerapan model pembelajaran kooperatif tipe Jigsaw berbantuan reviu pokok bahasan untuk meningkatkan aktivitas dan hasil belajar mahasiswa dalam mata kuliah Teknologi Air dan Pengolahan Limbah Industri belum memberikan hasil yang memuaskan karena porsi mahasiwa yang memperoleh nilai $\mathrm{A}$ dan $\mathrm{B}$ baru $82 \%$ sementara tingkat keberhasilan yang ditetapkan adalah lebih atau sama dengan $85 \%$.

- Persepsi mahasiwa terhadap model pembelajaran ini sangat positif. Sebanyak $82 \%$ mahasiswa berpendapat bahwa model pembelajaran ini dapat diteruskan dengan beberapa pengembangan yang disesuaikan dengan kondisi mahasiswa dan sifat materi pelajaran.

\section{Saran}

Untuk memperoleh hasil yang optimal dalam penerapan model pembelajaran kooperatif tipe Jigsaw berbantuan reviu pokok bahasan, khususnya untuk meningkatkan hasil belajar mahasiswa, perlu dilakukan dengan modifikasi-modifikasi atau peran dosen dalam pembelajaran perlu ditingkatkan yang disesuaikan dengan tingkat kesulitan materi.

\section{UCAPAN TERIMA KASIH}

Padakesempatan ini, penulis mengucapkan banyak terima kasih kepada semua pihak yang telah membantu penulis dalam penelitian dan penulisan artikel ini terutama Prof. Dr. I Wayan Santyasa, M.Si. yang telah banyak membantu penulis sehingga penulis dapat menyelesaikan artikel ini.

\section{DAFTAR PUSTAKA}

Cooper, M.M., 1995. “Cooperatif Learning". Journal of Chemical Education 72 (2) 162 -164.

Fosnot, C. T. 1989. Enquiring Teachers Enquiring Leaners Constructivist Approach for Teaching. New York: Teacher College Press.

Ibrahim, M., Fida R., Nur, M. dan Ismono. 2000. Pembelajaran Kooperatif. Surabaya: Unesa Press.

Jacobs, G. M., Siowek Lee, Gan. and Ball, Jessica. 1996. Learning Cooperative Learning Via Cooperative Learning (A Sourcebook of Lesson Plans for Teacher Education on Cooperative Learning). Singapore.SEAMEO Regional Language Centre Singapore.

Lungdren, L. 1994. Cooperative Learning in The Science Classroom. New York : McGraw Hill Company.

Nur, M. dan Wikandari, R. P. 1998. Pendekatan-Pendekatan Konstruktivis dalam Pembelajaran. Surabaya : IKIP Surabaya.

Retug, N. dan Syaban, S. 2004. "Penerapan Model Pembelajaran Kolaboratif untuk meningkatkan Aktivitas dan Hasil Belajar Mahasiswa dalam Perkuliahan Kimia Fisika I". Laporan Penelitian: Lemlit IKIP Negeri Singaraja. 
Yusuf, 2003. "Kualitas Proses dan Hasil Belajar Biologi Pokok Bahasan Aksi Interaksi Melalui Pengajaran dengan Model Pembelajaran Kooperatif Tipe Jigsaw pada
Madrasah Aliyah Kelas I Ponpes Nurul Haramain Putri Narmada Lombok Barat NTB". Laporan Penelitian: PPs Universitas Negeri Surabaya. 